\begin{tabular}{|c|c|c|}
\hline \multirow[t]{2}{*}{$\frac{\mathrm{DE}}{2}$} & $\begin{array}{l}\text { DE GRUYTER } \\
\text { OPEN }\end{array}$ & ECONOMIC THEMES (2016) 54(4): 469-483 \\
\hline & & DOI 10.1515/ethemes-2016-0023 \\
\hline
\end{tabular}

\title{
DEMOGRAPHICS, MIGRATION AND BRAIN DRAIN IN THE DANUBE REGION
}

\author{
Mirko Savić \\ University of Novi Sad, Faculty of Economics Subotica, Republic of Serbia \\ 凶savicmirko@ef.uns.ac.rs \\ Stojanka Dakić \\ University of Novi Sad, Faculty of Economics Subotica, Republic of Serbia \\ $\bowtie$ stojankad@ef.uns.ac.rs
}

UDC

341

Original

scientific

paper

\begin{abstract}
In the last two decades we have been witnessing the decrease of population in many countries of the Danube Region. All demographic indicators are unfavourable. Current demographic situation and labour market in the countries of the Danube Region is presented. The purpose of this paper is to evaluate the effects of demographic decline in the countries of the Danube Region on the key labour market variables and to model their behaviour. Also, the purpose of this paper is to analyse and discuss the possible consequences of demographic decline and the roles of migration and brain drain in the region. The main conclusion is that drop in the population growth is compensated with migration flows and prolongation of working life when it comes to the active labour force in

Received: the Danube Region, although population is still a main source of
\end{abstract} 10.06.2016. working force.

Accepted: Keywords: demographics, labour market, migration, Danube Region

17.01.2017.

JEL classification: J11, J13

\section{Introduction}

The positive correlation between the size of population and the size of labour force is natural and logical. Although this relation was the subject of many research studies in demographics and economics, it was not so much in the focus of policy makers in the field of economy. With the beginning of demographic decline across European countries, the policy makers are more and more aware of economic 
consequences of negative demographic trends and many countries are making efforts to fight population decline.

One of the most endangered regions in Europe from the aspect of demographical decline is the Danube Region."The Danube Region is the only macro region in the EU where the population is decreasing. The decrease has both natural and migratory reasons.” (Gal, Lux \&Illes, 2013).

Projection of the population decline in the future and the growing share of older cohorts within the shrinking population (Eurostat, 2016) will be inevitably influencing the expected economic development, changes in consumption needs, social priorities etc.

One the one hand, the countries of the Danube Region are sharing not only the same river and territory, but also the same problems. On the other side, the region is very heterogeneous in its nature. "The division of the Danube Region follows not only political-state aspects, but ethnically, linguistically, religiously and culturally it is one of the most diverse and mosaic-patterned territories of Europe" (Gal, Lux \& Illes, 2013).

The European Commission has developed the strategy for the Danube Region as a sustainable framework for policy integration and coherent development of the entire region (European Commission, 2010). The strategy is followed by accompanying document - Action Plan (European Commission, 2010), as its operationalisation. The Danube Strategy addresses several important issues across 4 main pillars (connecting the Region, protecting the environment, building prosperity, and strengthening the Region) and 11 Priority Areas, but very small part is dedicated to demographic problems in the region. In the Action Plan demographic challenges are mentioned under the 9th priority area which is defined as "investment in people and skills". One action under this area is focused "to improve cross-sector policy coordination to address demographic and migration challenges. Enhanced efforts should be pursuit to develop knowledge on the status quo, on drivers and impacts of migration flows and demographic change, so to develop a basis for enhanced cooperation of different policies at all levels of governance. Cross-sector policy coordination between relevant government departments, education authorities, social services, healthcare services, cultural policy authorities, housing and spatial planning authorities as well as asylum and immigration services at local, regional and national level, as well as dialogue with civil society are essential to ensure an adequate level of support. "This action is actually more focused towards migration as one of the many demographic problems in the region, like low fertility rates, brain drain, abortions, ageing etc. although ageing and brain drain are indirectly mentioned through development of knowledge society as one of the priorities. 
The purpose of this paper is to evaluate the effects of demographic decline in the countries of the Danube Region on the key labour market variables and to model their behaviour. Also, the purpose of this paper is to analyse and discuss the possible consequences of demographic decline and the issues of migration and brain drain in the region. On the basis of available Eurostat data about population and labour market indicators, we have tried to model the behaviour of key labour market indicators on the basis of current population trends.

This paper is organised as follows. After introduction, in the next three chapters we present key facts about current demographic situation in the region, migration, brain drain and labor market situation in the Danube Region. In the fifth chapter there is short presentation of implemented scientific methodology, and in the sixth presentation of results and obtained models. The last chapter is dedicated to discussion and conclusions.

\section{Demographic Decline}

The Danube Region covers 14 countries with around 156,7million residents. Nine of them are the members of the European Union (Germany, Austria, Hungary, the Czech Republic, Slovak Republic, Slovenia, Bulgaria, Romania, and Croatia), two recognised EU candidates (Serbia and Montenegro), one potential candidate (Bosnia and Herzegovina), and two countries (Moldova and Ukraine) included into the European Neighborhood Policy (ENP).With exceptions of Germany and Ukraine, it can be concluded that all other countries belong to the group of countries with small and medium population numbers. "In terms of population density - except for Montenegro - these figures cluster around the value of 100 people per km2” (Illes, 2002).

Table 1 shows the population trends in the Danube Region from 1960. It is obvious that since 1990 demographic decline has started in many countries in the region, especially in former socialist countries, with significant population fall in Bulgaria, Romania, Ukraine, Croatia and Serbia. On the other hand, we are witnessing population growth in the European Union as a whole, and very strong growth in neighbouring Turkey. Turkey is here to serve as a contrast to demographic decline in the region and to imply potential variations in the near future.

Demographic decline is followed by ageing of population. This factor will influence not only the overall economic development but it also generate unfavourable trends in social policy as well. It will reduce labour market reserves and make pressure on governments to dedicate significant financial funds toward increasing number of retirees. This will cause the slowing down of the catching-up process in the less developed countries. 
Table 1. Population on 1 January in the countries of the Danube Region, $\mathbf{E U}(28)$ and Turkey (in millions)

\begin{tabular}{|l|c|c|c|c|c|c|c|c|}
\hline \multicolumn{1}{|c|}{ GEO/TIME } & $\mathbf{1 9 6 0}$ & $\mathbf{1 9 7 0}$ & $\mathbf{1 9 8 0}$ & $\mathbf{1 9 9 0}$ & $\mathbf{2 0 0 0}$ & $\mathbf{2 0 1 1}$ & $\mathbf{2 0 1 4}$ & $\mathbf{2 0 1 5}$ \\
\hline $\begin{array}{l}\text { European Union (28 } \\
\text { countries) }\end{array}$ & 406.73 & 439.87 & 461.65 & 475.16 & 486.83 & 504.49 & 506.94 & 508.45 \\
\hline Bulgaria & 7.83 & 8.46 & 8.85 & 8.77 & 8.19 & 7.37 & 7.25 & 7.20 \\
\hline Czech Republic & 9.64 & 9.91 & 10.32 & 10.36 & 10.28 & 10.49 & 10.51 & 10.54 \\
\hline Germany & 72.54 & 78.27 & 78.18 & 79.11 & 82.16 & 81.75 & 80.77 & 81.20 \\
\hline Croatia & 4.13 & 4.40 & 4.60 & 4.77 & 4.50 & 4.29 & 4.25 & 4.23 \\
\hline Hungary & 9.96 & 10.32 & 10.71 & 10.37 & 10.22 & 9.99 & 9.88 & 9.86 \\
\hline Austria & 7.03 & 7.46 & 7.55 & 7.64 & 8.00 & 8.38 & 8.51 & 8.58 \\
\hline Romania & 18.32 & 20.14 & 22.13 & 23.21 & 22.46 & 20.20 & 19.95 & 19.87 \\
\hline Slovenia & 1.58 & 1.72 & 1.89 & 2.00 & 1.99 & 2.05 & 2.06 & 2.06 \\
\hline Slovakia & 3.97 & 4.54 & 4.96 & 5.29 & 5.40 & 5.39 & 5.42 & 5.42 \\
\hline Montenegro & & & & & 0.60 & 0.62 & 0.62 & 0.62 \\
\hline Ukraine & & & & & 49.11 & 45.60 & 45.24 & 42.76 \\
\hline Serbia & & & & & 7.53 & 7.25 & 7.15 & 7.11 \\
\hline Bosnia and Herzegovina & 3.21 & 3.69 & 4.14 & 4.50 & 3.75 & 3.84 & & \\
\hline Moldova & & & & & 3.64 & 3.56 & 3.56 & \\
\hline Turkey & 27.12 & 34.88 & 44.02 & 55.49 & 66.89 & 73.72 & 76.67 & 77.70 \\
\hline
\end{tabular}

Source: Eurostat, retrieved March 10 ${ }^{\text {th }}$ 2016, from: http://ec.europa.eu/eurostat/help/neweurostat-website.

The following two tables show the youngest and oldest cohorts in the countries of the Danube Region. We have the drastic decrease of young population in the entire region. In comparison with 1960, in 2015 there is approximately 12 million less youth, or from 1990 to 2015 approximately 8 million. Data for the EU(28 countries) are covering only last six years, but there is small increase of the same population. For Moldavia and Bosnia and Herzegovina, data were not available.

Table 2. Population less than 15- year-olds (in millions) in the countries of the Danube Region and $\mathbf{E U}(28)$

\begin{tabular}{|l|c|c|c|c|c|c|c|c|c|c|c|}
\hline \multicolumn{1}{|c|}{ GEO/TIME } & $\mathbf{1 9 6 0}$ & $\mathbf{1 9 7 0}$ & $\mathbf{1 9 8 0}$ & $\mathbf{1 9 9 0}$ & $\mathbf{2 0 0 0}$ & $\mathbf{2 0 1 0}$ & $\mathbf{2 0 1 1}$ & $\mathbf{2 0 1 2}$ & $\mathbf{2 0 1 3}$ & $\mathbf{2 0 1 4}$ & $\mathbf{2 0 1 5}$ \\
\hline $\begin{array}{l}\text { European Union } \\
\text { (28 countries) }\end{array}$ & & & & & & 78.97 & 79.09 & 79.10 & 79.13 & 79.16 & 79.37 \\
\hline Bulgaria & 2.05 & 1.94 & 1.96 & 1.80 & 1.30 & 0.98 & 0.98 & 0.98 & 0.99 & 1.00 & 1.00 \\
\hline Czech Republic & 2.47 & 2.12 & 2.41 & 2.25 & 1.71 & 1.49 & 1.52 & 1.54 & 1.56 & 1.58 & 1.60 \\
\hline Germany & 15.25 & 18.20 & 14.67 & 12.64 & 12.90 & 11.02 & 10.94 & 10.83 & 10.74 & 10.64 & 10.69 \\
\hline Croatia & & & & & & 0.66 & 0.65 & 0.65 & 0.64 & 0.63 & 0.62 \\
\hline Hungary & 2.53 & 2.18 & 2.34 & 2.13 & 1.73 & 1.48 & 1.46 & 1.44 & 1.43 & 1.43 & 1.43 \\
\hline
\end{tabular}




\begin{tabular}{|l|l|l|l|l|l|l|l|l|l|l|l|}
\hline Austria & 1.53 & 1.82 & 1.56 & 1.34 & 1.37 & 1.25 & 1.23 & 1.22 & 1.22 & 1.22 & 1.25 \\
\hline Romania & & 5.24 & 5.88 & 5.51 & 4.16 & 3.21 & 3.20 & 3.18 & 3.14 & 3.09 & 3.08 \\
\hline Slovenia & & & & 0.42 & 0.32 & 0.29 & 0.29 & 0.29 & 0.30 & 0.30 & 0.30 \\
\hline Slovakia & 1.25 & 1.25 & 1.30 & 1.35 & 1.07 & 0.84 & 0.83 & 0.83 & 0.83 & 0.83 & 0.83 \\
\hline Montenegro & & & & & 0.13 & 0.12 & 0.12 & 0.12 & 0.12 & 0.12 & 0.12 \\
\hline Ukraine & & & & & & 6.48 & 5.49 & 6.53 & 6.62 & 6.71 & 6.45 \\
\hline Serbia & & & & & 1.25 & 1.11 & 1.05 & 1.04 & 1.03 & 1.02 & 1.02 \\
\hline
\end{tabular}

Source: Eurostat, retrieved March 10 ${ }^{\text {th }}$ 2016, from: http://ec.europa.eu/eurostat/help/neweurostat-website.

At the same time, the number of oldest citizens is growing significantly. Their number is increasing again in all the countries in the region. In 2015, in comparison with 1990 there were approximately 9 million more people older than 65 years of age. In Germany in the same period there is increase of 5.3 million of oldest people. One of the explanations is better living conditions, which is followed by longer life expectancy. In 2013, live expectancy was lowest in Bulgaria (70.9 years for males and 78.1 for females) and highest in Germany and Austria (78.6 years for males and 83.2 for females).

Table 3. Population of 65- year-olds or over (in millions) in the countries of the Danube Region and EU(28)

\begin{tabular}{|l|c|c|c|c|c|c|c|c|c|c|c|}
\hline \multicolumn{1}{|c|}{ GEO/TIME } & $\mathbf{1 9 6 0}$ & $\mathbf{1 9 7 0}$ & $\mathbf{1 9 8 0}$ & $\mathbf{1 9 9 0}$ & $\mathbf{2 0 0 0}$ & $\mathbf{2 0 1 0}$ & $\mathbf{2 0 1 1}$ & $\mathbf{2 0 1 2}$ & $\mathbf{2 0 1 3}$ & $\mathbf{2 0 1 4}$ & $\mathbf{2 0 1 5}$ \\
\hline $\begin{array}{l}\text { European Union } \\
\text { (28 countries) }\end{array}$ & & & & & & 87.86 & 88.75 & 90.35 & 92.23 & 94.00 & 95.98 \\
\hline Bulgaria & 0.58 & 0.80 & 1.04 & 1.14 & 1.32 & 1.35 & 1.36 & 1.38 & 1.40 & 1.42 & 1.44 \\
\hline Czech Republic & 0.91 & 1.18 & 1.40 & 1.29 & 1.42 & 1.60 & 1.64 & 1.70 & 1.77 & 1.83 & 1.88 \\
\hline Germany & 8.31 & 10.59 & 12.26 & 11.79 & 13.35 & 16.90 & 16.84 & 16.88 & 17.00 & 16.85 & 17.09 \\
\hline Croatia & & & & & & 0.77 & 0.76 & 0.77 & 0.77 & 0.78 & 0.80 \\
\hline Hungary & 0.89 & 1.18 & 1.45 & 1.37 & 1.53 & 1.66 & 1.67 & 1.68 & 1.70 & 1.73 & 1.76 \\
\hline Austria & 0.85 & 1.04 & 1.17 & 1.14 & 1.23 & 1.47 & 1.48 & 1.50 & 1.53 & 1.56 & 1.58 \\
\hline Romania & & 1.72 & 2.28 & 2.38 & 2.96 & 3.27 & 3.26 & 3.24 & 3.26 & 3.30 & 3.38 \\
\hline Slovenia & & & & 0.21 & 0.28 & 0.34 & 0.34 & 0.35 & 0.35 & 0.36 & 0.37 \\
\hline Slovakia & 0.27 & 0.41 & 0.52 & 0.54 & 0.62 & 0.67 & 0.68 & 0.69 & 0.71 & 0.73 & 0.76 \\
\hline Montenegro & & & & & 0.07 & 0.08 & 0.08 & 0.08 & 0.08 & 0.08 & 0.09 \\
\hline Serbia & & & & & 1.20 & 1.24 & 1.25 & 1.25 & 1.26 & 1.29 & 1.31 \\
\hline
\end{tabular}

Source: Eurostat, retrieved March $10^{\text {th }}$ 2016, from: http://ec.europa.eu/eurostat/help/neweurostat-website. 
Other demographic indicators are also unfavourable. Total fertility rate (number of new born babies per mother in fertile period (15-49 years of age)) in 1960 was between 2 and 3 babies across region, but in 2015 it was from 1.37 in Slovakia to 1.75 in Montenegro, which is far from enough for population reproduction. In Turkey, for example, total fertility rate is 2.17. In EU(28) it is 1.58(Eurostat, 2016).

Crude marriage rate (number of marriages per 1000 citizens) is also decreasing significantly. In 1960 it was between 7.7 in the Czech Republic and 10.1 in Bosnia and Herzegovina and 10.7 in Romania. In 2013 (latest available data) crude marriage rate is spanning between 3.0 in Bulgaria and Slovenia and 6.4 in Montenegro (Eurostat, 2016). This phenomena influences and changes our basic attitudes towards marriage, families, children, their upbringing, population and other social categories which at the end has its reflection on the labour market and economy as a whole.

Parallel with the reduction of marriages goes the increase of divorces in the Danube Region. Number of divorces per 100 marriages in EU in 2011 was 46.1 (latest available data). In 1960, in the Danube Region the same indicator went from 7.2 in Slovakia and 10.7 in Germany to 18.7 in Hungary and Romania. In 2013, the number of divorces per 100 marriages goes from 13 in Montenegro, 22.6 in Serbia and 26.5 in Romania to 54.6 in Hungary and 64.1 in the Czech Republic.

Decrease of marriages has brought one more change in our society. The proportion of newly born children outside marriage has been increasing dramatically. In the entire EU, that proportion is $40 \%$ in 2012 (latest available data), while the same proportion in the Danube Region in 1960 was from $4.7 \%$ in Slovakia, $4.9 \%$ in the Czech Republic and 5.5\% in Hungary to $13 \%$ in Austria. In 2014, the lowest share of live births outside marriage in the Danube Region is in Croatia (17.4\%) and Serbia (25.1\%), while the highest is in Bulgaria (58.8\%), Slovenia (58.3\%) and Hungary (47.3\%) (Eurostat, 2016).

Mean age of women at childbirth is increasing in all the countries in the region. In 1960 for example mean age was 25.1 years in Bulgaria and 27.6 in Austria, while in 2014 it goes from 27.3 in Bulgaria and 27.5 in Romania to 30.4 in Austria and Bulgaria and 30.9 in Germany. Increase of mean age of women in childbirth is followed by decrease of probability that woman will have more than one child in the future.

Legally induced abortions have showed decrease in the last decade, but statistics of induced abortions are not reliable because of significant number of illegal abortions.

Additionally, there is specific demographic problem of Roma population, which is estimated at approximately 12 million living in the EU. Half of that 
number is living in the Danube Region and their number is growing. Majority of them are living under conditions of extreme poverty and deprivation.

These dramatic changes in the Danube Region, especially in the case of former socialist countries are explained by the theory of Second Demographic Transition. "Second Demographic Transition is the transformation from traditional way of population reproduction, which is characteristic of underdeveloped societies with high fertility and mortality rates, to a modern way of reproduction, which is characteristic of developed societies with low fertility and mortality rates." (Savić, 2007). Demographic consequences of economic transition in countries of Central and Eastern Europe, with the overview of countries in the Danube Region is well explained in Philipov and Dorbritz (2003).

Theory of demographic transition is trying to explain changes in the population reproduction of Western European countries at the end of XIX century and at the beginning of XX century, which is called First Demographic Transition.

Today, socio-economic development has brought to us great individualisation in the society and the individualisation of reproduction. The balance between fertility and mortality rates was not established. The accent is on the post-industrial society with different patterns and expectations in changed socio-cultural environment. We are now talking about Second Demographic Transition.

According to Landry (1934), the fundamental principle of the first transition was the rationalisation of life, and the fundamental principle of the second demographic transition is the right to self-realisation granted to each individual and the demystification of social control according to Van de Kaa (1998).

\section{Migration and Brain Drain}

We are witnessing strong migration pressure in recent years from Middle East on European countries. Although it is very difficult to predict all consequences of such phenomena, migration represents one of the solutions for population decline in the Danube Region. On the other hand, it raises many political, social and economic questions. What can we expect in the future when it comes to migration? Without migration population drop in the region will be dramatic. The following table shows population forecast in the following 45 years for available countries in the Eurostat database (reduced variant). It is obvious that even with the controlled migration influence we can expect the decrease in population across the region with two small exceptions in the case of the Czech Republic and Austria. 
Table 4. Population forecast: Reduced migration variant - Population on $1^{\text {st }}$ January

\begin{tabular}{|l|c|c|c|c|c|c|}
\hline \multicolumn{1}{|c|}{ GEO/TIME } & $\mathbf{2 0 1 5}$ & $\mathbf{2 0 2 0}$ & $\mathbf{2 0 3 0}$ & $\mathbf{2 0 4 0}$ & $\mathbf{2 0 5 0}$ & $\mathbf{2 0 6 0}$ \\
\hline $\begin{array}{l}\text { European Union } \\
\text { (28 countries) }\end{array}$ & 508.0 & 511.3 & 514.6 & 515.9 & 513.7 & 506.9 \\
\hline Bulgaria & 7.2 & 7.0 & 6.5 & 6.1 & 5.8 & 5.5 \\
\hline Czech Republic & 10.5 & 10.6 & 10.7 & 10.7 & 10.7 & 10.7 \\
\hline Germany & 80.7 & 80.3 & 78.9 & 76.4 & 72.9 & 68.7 \\
\hline Croatia & 4.2 & 4.2 & 4.1 & 3.9 & 3.8 & 3.6 \\
\hline Hungary & 9.9 & 9.8 & 9.6 & 9.4 & 9.1 & 8.9 \\
\hline Austria & 8.5 & 8.7 & 9.1 & 9.3 & 9.3 & 9.2 \\
\hline Romania & 19.9 & 19.7 & 19.0 & 18.5 & 18.0 & 17.4 \\
\hline Slovenia & 2.1 & 2.1 & 2.1 & 2.0 & 2.0 & 2.0 \\
\hline Slovakia & 5.4 & 5.4 & 5.3 & 5.1 & 4.8 & 4.5 \\
\hline
\end{tabular}

Source: Eurostat, retrieved March $10^{\text {th }}$ 2016, from: http://ec.europa.eu/eurostat/help/neweurostat-website.

Beside migration inflow from outside Europe, there are also significant migration flows inside the continent and the Danube Region. These flows are always connected with the issue of brain drain in many countries of Eastern Europe. Major part of countries in the Danube Rgion are so-called "sending countries”., while only two are "receiving countries” (Austria and Germany).

Highly qualified labour force from the East is looking for job opportunities in the West, starting mostly during their education and studies. According to Eurostudent(2015), mobility flows from Eastern and Southern EHEA (European Higher Education Area) countries to Western end Northern EHEA but also between countries of North-Western EHEA are imbalanced. Consequently, importexport ratio of internationally mobile students in the countries of the region is unfavorable. Only Austria, Germany, the Czech Republic and Hungary have positive balance.

Is there real threat of brain drain as the consequence of international student mobility for the mostly sending countries? According to Gibson and McKenzie (2010), among the highly skilled workforce there are very intensive emigration and return migration with large positive benefits for high emigration countries. The authors are also underlying the benefits for source countries in terms of knowledge flows and sending remittances but with rare cases of engaging in trade or foreign direct investment.

Chevalier (2014) is summarising the main pros and cons of international student migration. The positive sides are that student mobility can foster economic growth both in sending and receiving countries, student mobility can influence the 
wage growth for the migrants, and elimination of visa restriction will increase the quantity and quality of international students in host countries. On the other side, there is a risk of brain drain for source countries, economic growth can suffer because of student migration, source countries incur fiscal costs due to absence of a qualified and skilled workforce, and target countries are facing fiscal costs through subsidizing foreign students.

"The brain drain has long been viewed as a serious constraint on poor countries development. However, recent theoretical literature suggests that migration prospects can raise the expected return to human capital and foster investment in education at home." (Beine, Docquier \& Rapoport, 2008). "Even if a certain number of international students decide to stay abroad after their studies, the brain drain will not have exclusively negative effects for sending countries, because it will still contribute to human capital formation, development of domestic educational system, return migration with additional skills acquired abroad, creation of scientific and business networks, remittances, etc.” (Savić, Kresoja \& Živadinović, 2014).

\section{Population and Labour Market in Danube Region}

Population decline has its influence on the labour market in the Danube Region through shrinking of labour force and decrease of activity rates. Beside that factor, many countries in the region went through transition period from centralised to market economy, which caused negative variations on the labour market, like job losses and sharp decrease in employment in less productive sectors. In the Danube Region "the ratio of the economically active within the total population is less than the European average.” (Gal, Lux \& Illes, 2013). Additional problem is informal economy. "The informal economy: a review of the labour market could not be undertaken in a large part of the region without mention of the informal economy. By its very nature, measuring the size of the informal economy is problematic. However, it is evident that in the Western Balkans, it is a substantial sector in its own right” (OECD, 2010).Significant informal economy blurs the picture about the size of the labour force and labour market indicators in the region.

Table 5 shows the average pace of selected population and labour market indicators in the Danube Region and the European Union. For example, in the last 21 years population in the region is increasing each year on average for $0.11 \%$, while in EU the rate is $0.27 \%$. In the region, young population is decreasing faster while oldest population is increasing faster in comparison with EU. At the same time, active population is increasing slower, while employment is increasing faster. The explanation lies in the fact that immigration is making compensation for the lost labour force due to unfavourable population variations. Additional explanation is in the prolonged working life which also influences employment. It was not possible to make analysis for longer period of time because of the lack of data for 
EU and some countries in the Danube region, but the longer period would highlight disparities even more.

Table 5. Dynamics of selected population and labor market indicators in the Danube region and European Union

\begin{tabular}{|c|c|c|c|c|c|c|c|c|c|}
\hline 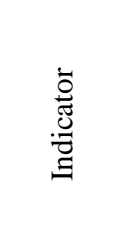 & 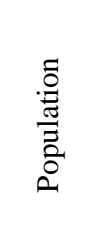 & 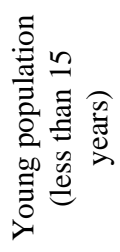 & 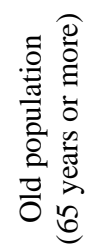 & 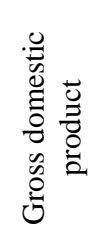 & 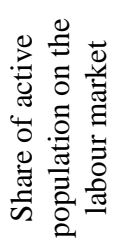 & 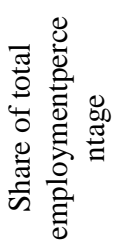 & 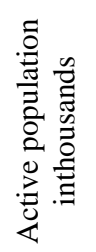 & 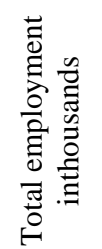 & 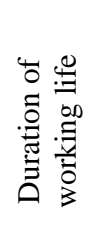 \\
\hline $\begin{array}{l}\text { Number } \\
\text { of years }\end{array}$ & 21 & 15 & 15 & 21 & 15 & 15 & 15 & 15 & 15 \\
\hline $\begin{array}{l}\text { Danube } \\
\text { Region }\end{array}$ & $0.11 \%$ & $-0.90 \%$ & $1.77 \%$ & $2.79 \%$ & $0.37 \%$ & $0.48 \%$ & $0.35 \%$ & $0.55 \%$ & $0.42 \%$ \\
\hline EU & $0.27 \%$ & $-0.33 \%$ & $1.57 \%$ & $3.55 \%$ & $0.40 \%$ & $0.33 \%$ & $0.55 \%$ & $0.49 \%$ & $0.50 \%$ \\
\hline
\end{tabular}

Source: Eurostat, retrieved March $10^{\text {th }}$ 2016, from: http://ec.europa.eu/eurostat/help/neweurostat-website, authors own calculations.

\section{Scientific Methods}

Our goal was to model the relation between population and labour market indicators on the basis of available Eurostat data. Unfortunately, many statistical data are available only from 1995, and for some countries data are missing (Ukraine, Moldavia, Serbia, Montenegro, Bosnia and Herzegovina). Also pretransition statistical data are not reliable for many reasons, especially because of different methodology and latent employment. Therefore, our panel data are unbalanced with 9 countries through 15 time periods (years).

Through modelling, the authors have implemented standard econometrical procedure for panel data series and model selection was based on the BreuschPagan test and Hausman test for the selection between fixed and random effects models.

\section{Results}

First, we have developed model to explore the relation between gross domestic product (gdp) as dependent variable and active population on the labour market and duration of working life on the other. On the basis of the Breusch-Pagan test ( $\mathrm{p}<$ 0.01 ) and the Hausman test ( $p>0.01)$ we can conclude that random-effects model is the best solution for this panel data, although p-value for the Hausman test lies between critical values of 0.01 and $0.05(p=0.03988)$. 


\section{Model 1. Random-effects (GLS), using 132 observations}

\begin{tabular}{|c|c|c|c|c|c|}
\hline \multirow{5}{*}{$\begin{array}{l}\text { const } \\
\text { activity_thousands } \\
\text { workinglife }\end{array}$} & \multicolumn{4}{|c|}{$\begin{array}{c}\text { Included } 9 \text { cross-sectional units } \\
\text { Time-series length: minimum 12, maximum } 15 \\
\text { Dependent variable: gdp }\end{array}$} & \\
\hline & Coefficient & Std. Error & t-ratio & p-value & \\
\hline & $-1.12298 \mathrm{e}+06$ & 212734 & -5.2788 & $<0.00001$ & $* * *$ \\
\hline & 62.2015 & 4.68213 & 13.2849 & $<0.00001$ & $* * *$ \\
\hline & 30052.5 & 6482.91 & 4.6357 & $<0.00001$ & $* * *$ \\
\hline Mean dependent var & 363780.1 & & S.D. depend & & 764545.2 \\
\hline Sum squared resid & $2.99 \mathrm{e}+12$ & & S.E. of regre & & 151589.5 \\
\hline Log-likelihood & -1760.911 & & Akaike crite & & 3527.822 \\
\hline Schwarz criterion & 3536.471 & & Hannan-Qui & & 3531.337 \\
\hline
\end{tabular}

On the basis of the obtained results we can conclude that there is statistically significant and positive relation between gross domestic product and active population on the labour market in the Danube Region. Labour market activity strongly influences economic performance. Additionally, prolongation of working life contributes positively to the growth of gross domestic product. Since, randomeffects model is the best one, we can conclude that despite economic and other disparities among the countries in the Danube Region and specific characteristics of each country, this model is valid across entire the Danube Region.

The second model is showing the nature of relation between active population as dependent variable and population growth as independent variable. On the basis of the Breusch-Pagan test $(\mathrm{p}<0.01)$ and the Hausman test $(\mathrm{p}<0.01)$ we can conclude that fixed-effects model is the best solution for this panel data.

\section{Model 2. Fixed-effects, using 164 observations}

Included 9 cross-sectional units Time-series length: minimum 13, maximum 21 Dependent variable: activity_thousands

$\begin{array}{lcclcl} & \text { Coefficient } & \text { Std. Error } & \text { t-ratio } & p \text {-value } & \\ \text { const } & 5568.08 & 1247.23 & 4.4643 & 0.00002 & * * * \\ \text { Population } & 0.000168076 & 6.89508 \mathrm{e}-05 & 2.4376 & 0.01592 & * * \\ \text { Mean dependent var } & 8607.518 & & \text { S.D. dependent var } & 12280.10 \\ \text { Sum squared resid } & 21805250 & \text { S.E. of regression } & 376.2878 \\ \text { R-squared } & 0.999113 & \text { Adjusted R-squared } & 0.999061 \\ \text { F(9, 154) } & 19271.85 & \text { P-value(F) } & 3.7 \mathrm{e}-230 \\ \text { Log-likelihood } & -1200.125 & \text { Akaike criterion } & 2420.250 \\ \text { Schwarz criterion } & 2451.249 & \text { Hannan-Quinn } & 2432.834 \\ \text { rho } & 0.916738 & \text { Durbin-Watson } & 0.135496\end{array}$

Test for differing group intercepts: Null hypothesis: The groups have a common intercept Test statistic: $F(8,154)=18.7528$, with p-value $=\mathrm{P}(\mathrm{F}(8,154)>18.7528)=1.84935 \mathrm{e}-019$ 
There is statistically significant, positive relation between population growth and active labour force. It is natural, but maybe surprisingly strong relation, almost perfect. Adjusted R-squared (coefficient of determination) is almost 1 (0.999061). That indicates that other factors influencing the size active labour force are very small. Since the fixed-effects model is the best one, it bring us to conclusion that each country in the Danube Region has some specific characteristics regarding the variation in the active labour force that are not included in the model. The logical explanation in that sense are different migration flows across countries and different labour market policies.

\section{Discussion}

The main conclusion is that drop in the population growth is compensated with migration flows and prolongation of working life when it comes to the active labour force in the Danube Region, although population is still main source of working force. Demographic situation is very serious and it is necessary to take synchronized action in the entire region to fight demographic decline. Strategy for the Danube Region is one step in the right direction, but only when it comes to migration inflows, educational policies and ageing in some sense. This approach could be explained by external migratory pressures in recent years because large masses already appear on the external borders of the region from North Africa and the Middle East. This is why migration management is increasingly becoming a strategic issue, but in the next four decades demographic decline will continue and we must pay attention to many other aspects such as fertility, abortion, health care, gender equality, disintegration of families, births outside the marriages, youth unemployment, full-time and part-time employment of parents etc.

The Danube Region is changing dramatically and we all share these changes, but the main threat to the region is its disintegration. "In political sense the Danube Region has always been historically fragmented and we can conclude that it is still the same even today. The majority of the small catchment area is divided among small states, representing so many competing interests” (Gal Z. , 2009).

There are so many differences dividing the region: nine countries of the region are the members of European Union (Germany, Austria, Croatia, Slovenia, Czech Republic, Slovakia, Hungary, Romania and Bulgaria). Some of EU countries in the region are the members of the Eurozone, and some of them are not. Some of them are the members of the Schengen zone and some of them are not. On the other side, five are not members of the integration (Ukraine, Moldova, Serbia, BosniaHerzegovina, Montenegro) and they are in different stages of negotiation process for EU accession. Some of them have serious political issues regarding its territory. 58 million people are still living outside the EU (approximately one third). This 
problematic and ambiguous situation is even more pronounced at the regional level within the countries.

Demographic variations in the Danube Region have negative impacts not only on the overall economic development of the Region but they also generate unfavourable trends in political relations between the countries as well.

Enlargement of the EU should bring the region, or at least the major part of it, to unified political and integrating economic entity, so that political obstacles to cooperation should be removed. "It is a strange characteristic of the procedure that the later a country applies for membership, the more and more difficult conditions they are expected to fulfil.” (Gal, Lux \& Illes, 2013).

The time is running out, and only harmonised action based on the common strategy can bring the solution for demographic decline and consequently for better labour market and safe future.

\section{References}

Beine, M., Docquier, F. \& Rapoport, H. (2008, April). Brain Drain and Human Capital Formation in Developing Countries: Winners and Losers. The Economic Journal(118), 631-652.

Chevalier, A. (2014, July). How to Attract Foreign Studens. Retrieved from: IZA World of Labor: wol.iza.org, Acessed on: August 29., 2014

European Commission. (2010). Action Plan - Accompanying document to the Communication from the Commission to the European Parilament, the Council, the European Economic and Social Committee and the Committee of the Regions European Union Strategy for the Danube Region. Brussels: European Commission.

European Commission. (2010). European Union Strategy for Danube Region. Brussels: European Commission.

Eurostat. (2016). Population Data. Retrieved from: Eurostat http://ec.europa.eu/eurostat/help/new-eurostat-website, Accessed on : March 10, 2016.

EUROSTUDENT. (2015). Social and Economic Conditions of Student Life in Europe, EUROSTUDENT V 2012-2015, Synopsis of Indicators. Bielefeld: Deutsches Zentrum fürHochschul-und Wissenschaftsforschung.

Gal, Z. (2009). The Danube region - past, present and future prospect of transnational cooperation as a playground of the European integration. Eurolimes. Journal of the Institute for Euroregional Studies(7), 148-158.

Gal, Z., Lux, G. \& Illes, I. (2013). Danube Region - Analysis and Long-Term Development Trends of the Macro-Region, Discussion Papers No. 90. Pecs, Hungary: Institute of Regional Studies Research Centre of Economic and Regional Studies, Hungarian Academy of Sciences.

Gibson, J. \& McKenzie, D. (2010). The Economic Consequences of "Brain Drain" of the Best and Brightest: Microeconomic Evidence from Five Countries. Hamilton, New Zealand: University of Waikato, Working Paper in Economics No. 10/05. 
Illes, I. (2002). Közép- és Délkelet-Európa az ezredfordulón. Átalakulás, integráció, régiók [Central and South Eastern Europe at the turn of the Millenium. Transformation, integration and regions]. Budapest-Pécs: Dialóg Campus Kiadó.

Landry, A. (1934). The Demographic Revolution. Paris: Institut National d'Etudes Demographiques in Paris.

OECD. (2010). Investment Reform Index 2010: Monitoring Policies and Institutions for Direct Investment in South-East Europe. Paris: OECD.

Philipov, D. \& Dorbritz, J. (2003). Demographic Consequences of Economic Transition in Countries of Central and Eastern Europe. Retrieved from: Population Studies No. 39: http://www.coe.int/t/e/social_cohesion/population/Publications/, Accessed on: October 10, 2006.

Savić, M. (2007). Risks of Second Demographic Transition in Eastern Europe. Strategic Management(3-4), 112-118.

Savić, M., Kresoja, M. \& Živadinović, I. (2014). International Mobility of Students in Western Balkan Countries. The Social Dimension in European Higher Education (p. 18). Vienna: EUROSTUDENT.

Van de Kaa, D. (1998). Is the Second Demographic Transition a Useful Research Concept - Questions and Answers. Retrieved from : http://hw.oeaw.ac.at/ 0xc1aa500d_0x0006201f, Accessed on: October 29, 2006.

\section{DEMOGRAFIJA, MIGRACIJE I ODLIV MOZGOVA U DUNAVSKOM PODRUČJU}

Apstrakt: U poslednje dve decenije svedoci smo smanjenja stanovništva $u$ mnogim zemljama Dunavskog regiona. Svi demografski pokazatelji su nepovoljni. Trenutna demografska situacija i na tržištu rada u zemljama Dunavskog regiona je prikazana. Cilj ovog rada je da se ispita uticaj demografskog pada u zemljama Dunavskog regiona na ključnim veličinama tržišta rada i da se dâ model njihovog ponašanja. Isto tako, svrha ovog rada je da se analizira i diskutuje o mogućim posledicama demografskog pada i uloge migracija i odliva mozgova u regionu. Glavni zaključak je da se pad rasta stanovništva kompenzuje migracionim tokovima i produženjem radnog veka kada su u pitanju aktivne radne snage u Dunavskom regionu, iako je stanovništvo i dalje glavni izvor radne snage.

Ključne reči: demografija, tržište rada, migracija, Dunavski region

\section{Authors' biographies}

Mirko Savić is a full professor at the Faculty of Economics in Subotica, at the Department for Business Informatics and Quantitative methods.He is also working at the University Center for Applied Statistics (University of Novi Sad), where he is teaching official statistics.Since 2015, Mirko Savić has been an active member of CAQA (Commission for Accreditation and Quality Assurance), Serbian HERE team (Higher Education Reform Expert), and Statistics Council of Republic of 
Serbia.He is also member of the following professional associations: AIEL Italian Association of Labor Economists, AEET - Spanish Association of Labor Economists, EURO - Association of European Operational Research Societies, EALE - European Association of Labor Economists, Statistical Society of Serbia, and Serbian Society of Economists.In his carrier he was engaged at the Faculty of Natural Sciences (University of Novi Sad, Department for Geography and Tourism), and at the Faculty for Public Administration (University "Ciryl and Method", Trnava, Slovakia). He is the author of two textbooks for statistics and over 70 scientific papers published in Serbia and abroad. The fields of professional interest are statistics, econometrics, multivariate analysis, demographics, labour market and higher education.

Stojanka Dakić is a teaching assistant at the Faculty of Economics in Subotica (University of Novi Sad), at the Department for Business Informatics and Quantitative methods. She graduated in 2005 at the Faculty of Economic in Subotica, as a student of generation and defended master's and doctoral thesis at the same faculty in 2009 and 2016, respectively. She was engaged as a teaching assistant at the University Center for Applied Statistics (University of Novi Sad). The fields of her professional interest are statistics, multivariate analysis, demographics, labour market and higher education. She is a coauthor of workbook for statistics and she published over 20 scientific papers in Serbia and abroad. She is a participant in ERASMUS project PT\&SCHE (Introduction of part-time and short cycle studies in Serbia: challenges and opportunities). Stojanka Dakić has been a member of the Statistical Society of Serbia since 2007. 